This item was submitted to Loughborough's Research Repository by the author.

Items in Figshare are protected by copyright, with all rights reserved, unless otherwise indicated.

\title{
Transgovernmental networks and rationalist outputs? The partial social construction of EU foreign policy
}

PLEASE CITE THE PUBLISHED VERSION

http://dx.doi.org/10.1080/09662839.2016.1236791

\section{PUBLISHER}

(c) Taylor \& Francis

\section{VERSION}

AM (Accepted Manuscript)

\section{PUBLISHER STATEMENT}

This work is made available according to the conditions of the Creative Commons Attribution-NonCommercialNoDerivatives 4.0 International (CC BY-NC-ND 4.0) licence. Full details of this licence are available at: https://creativecommons.org/licenses/by-nc-nd/4.0/

\section{LICENCE}

CC BY-NC-ND 4.0

\section{REPOSITORY RECORD}

Chelotti, Nicola. 2019. "Transgovernmental Networks and Rationalist Outputs? the Partial Social Construction of EU Foreign Policy”. figshare. https://hdl.handle.net/2134/24082. 


\title{
Transgovernmental networks and rationalist outputs? The partial social construction of EU foreign policy
}

\begin{abstract}
EU foreign policy has gone beyond intergovernmentalism. It is largely formulated by (Brusselsbased) national officials, in a process characterised by a high number of cooperative practices, diffuse sentiments of group loyalty and possibly argumentative procedures. Yet, in many cases, the most likely output of this process reflects the lowest common denominator of states' positions or the preferences of the biggest states. The article intends to investigate this puzzle. In the first part, it corroborates its existence by using answers from an original database of 138 questionnaires and 37 interviews with EU negotiators. Next, it argues that cooperative practices remain often subordinated to nationally-oriented ways of doing things. Consequentialist practices perform an anchoring function, in that they define the parameters around which (social) practices operate. The last section looks more closely at the sites of and meanings attached to EU foreign policy-making. By discussing national diplomats' conspicuous leeway in Brussels, it also argues that negotiating practices are performed through a mix of partial agency and persistence of national dispositions. On a whole, changing practices is difficult, even in dense and largely autonomous settings such as EU foreign policy. The social construction of EU foreign policy occurs only to a partial extent.
\end{abstract}

There is wide consensus that the foreign policy of the European Union (EU) has moved beyond intergovernmentalism. Although cooperation in foreign policy remains firmly in the hands of the member states, primarily gathered in the Council of the EU (hereafter: Council), the interactions between national representatives are hardly characterised by bitter disputes among ministers, zero-sum negotiations and detailed cost-benefit analyses of every diplomatic move. This consensus is built on very solid grounds. The literature has convincingly revealed that EU foreign policy is, to a large extent, formulated by groups of officials who, being mostly based in Brussels and sharing a set of common practices, engage autonomously (from the cabinets) in policy making. These dynamics produce a culture of consensus, which instils EU foreign policy with cooperative solutions and (possibly) collectively legitimised policies (e.g., Bicchi 2011; Cross 2011; Howorth 2012; Juncos and Reynolds 2007; Sjursen 2011; Tonra 2003). Yet, against this backdrop, anecdotal evidence is rich of examples of EU's continuous failures to find far-reaching agreements in several areas or on several issues of international politics. As recently, the EU has struggled to agree on responses to the crises in Syria, Egypt or Mali. It still presents widely diverging views on how to approach Libya or Yemen, let alone Turkey on the Cyprus question (European Council of Foreign Relations 2015). 
A puzzle emerges. EU foreign policy is a highly institutionalised regime, where a relatively autonomous group of diplomats share a high number of cooperative practices. At the same time, these practices appear to constantly produce nationally-oriented outputs. This article intends to further investigate this puzzle. In the first part, it validates the existence of this conundrum, by relying on a series of questionnaires and interviews with participants to the decision-making process of the Common Foreign and Security Policy (CFSP) and the Common Security and Defence Policy (CSDP). It reveals that, in case of divergences, a very likely outcome of the negotiation process is an agreement which reflects the lowest common denominator of states' positions or the preferences of the largest countries. The second part identifies some factors that explain this puzzle. Understanding practices as socially meaningful patterns of action, it argues that greater attention should be paid to the entire practical structure of diplomatic interactions. Cooperative practices have not supplanted, while often being subordinated to, consequentialist ways of doing things. Interest- and powerbased relationships are accepted and regularly performed by national diplomats in the Council. Consequentialist practices perform an anchoring function, in that they define the parameters around which other (e.g., social) practices operate (Bicchi and Bremberg 2016). The last section of the article looks more closely at the sites of EU foreign policy making, and explores the meanings around some of the practices that are carried there out. It briefly speculates on the role of agency in performing practices. On a whole, changing (consequentialist) practices is difficult: even dense and largely autonomous settings such as EU foreign policy struggle to generate the conditions for consequential change to happen. The social construction of EU foreign policy occurs only to a partial extent.

\section{The puzzle: transgovernmental networks, social practices and rationalist outputs}

\section{Transgovernmental networks and social practices}

Even after the entry into force of the Lisbon treaty, the CFSP/CSDP remains, formally, a largely intergovernmental project: the member states are the drivers of the process, as the Council (and the European Council) are the key decision-making bodies, and unanimity is (with very few exceptions) the rule. Yet, scholars who have investigated more closely the 
context and structure of the CFSP/CSDP soon realised that the decision-making processes do not follow strictly intergovernmental templates, in a number of aspects.

First, negotiations are better understood in terms of transgovernmental, rather than intergovernmental, processes. Transgovernmentalism indicates that sub-units of governments engage directly and autonomously (from the executives) in policy-making interactions (Slaugther 2004). In the well-known definition of Keohane and Nye (1974: 43), transgovernmental relations are "sets of direct interactions among sub-units of different governments that are not controlled or closely guided by the policies of the cabinets or chief executives of those governments". The decision-making process of the CFSP/CSDP is dominated by ministerial officials: elected politicians as well as non-state actors (Mérand et al. 2010) are (relatively) marginal in the daily negotiating process. The top echelons of the government intervene only occasionally - when particularly important or controversial issues are at stake. It is widely known that the majority of policy dossiers are finalised by national officials sitting in Council committees, and then formally adopted by ministers without any further discussion by them. The policy process is disaggregated and the power has shifted from national politicians to the civil servants in the ministry (Adler-Nissen 2014). Significantly, a second disaggregation takes place, which moves the policy process even more beyond intergovernmentalism. Within national ministries, relevant decision-making tasks are performed by single officials based in the national permanent representations (PRs) in Brussels. They often enjoy some degree of autonomy in the preparation and negotiation of the policy, vis-a-vis the ministerial departments in the capital (Chelotti 2013; Cross 2011). Incidentally, this leeway opens us space for individual agency in EU politics. For instance, in a rapid decision-making environment the terms of compromises are often identified and struck by single negotiators, in individual capacity, not (necessarily) according to wellestablished and hierarchically organised sets of preferences.

Second, national officials operating in CFSP/CSDP transgovernmental networks share a high number of practices, which regulate the proper conduct of negotiations in the Council (AdlerNissen 2014). The high frequency of diplomats' meetings, the information system that has been created within and around EU foreign policy have contributed to create 'a community of practitioners who have developed a shared repertoire of resources for negotiating meaning' (Bicchi 2011: 1116). The common trait of this practical knowledge is that they orient the negotiation process towards cooperative solutions. Cooperation has gone beyond mere discussions about policy coordination (i.e., 'cheap talk') but it has intensified to the point of 
generating, at minimum, trust or, more substantively, shared understandings and approaches to problems (M.E. Smith 2003).

Some of these practices are procedural: national representatives quickly learn the group professional norms, which concern the group’ protocol, procedures and consensus-building practices (Cross 2011). Coordination reflexes among national diplomats are particularly significant. They denote that there is a formalized political obligation for national delegations to contact their European partners before and during the formulation of the national position (Tonra 2001). The exchange of information is very high. As a diplomat reports, 'We receive even too much information, we are often overwhelmed by high-quality information, mostly from our EU partners, especially in those areas where our network' is limited ${ }^{1}$. The national and European layers of policy-making become blurred, which has the potential to endogenise the construction of the national preference. Diplomats have internalized joint action and coherence as intrinsic values of EU foreign policy. Reaching an agreement is considered a value in itself, together with the responsibility to make the system work (Lewis 2005). At the same time, EU foreign policy contains also substantive policy commitments (human rights, democracy, poverty, multilateralism etc.) which make negotiating positions converge over time (Thomas 2011).

Third, the social context of the CFSP/CSDP helps to create an esprit de corps and a sense of community among diplomats. More incisively, CFSP/CSDP institutions (may) reshape also officials' interests and identities (Tonra 2003), developing 'we-feelings', identifications with one another and, in some cases, 'European' role conceptions. National diplomats expand the conception of their self to include other-regarding behavior (Tonra 2001). In some instances, they are socialized to EU values and increasingly act as Europeans (Chelotti 2015; Howorth 2012; Juncos and Reynolds 2007).

Transgovernmentalism, shared practices, eventual socialization processes have a profound impact on the policy process. At the minimum, they place considerable limitations on state self-interest, thus leaving space for a more coherent and significant EU foreign policy. More incisively, they (can) lead to a collective way of doing politics. The fourth aspect of a beyond-intergovernmental process suggests that CFSP/CSDP committees also share a set of argumentative practices. Argumentative practices first of all refer to the conformity with the community's standards of legitimacy. In the CFSP/CSDP, actors who are able to justify their positions by appealing to EU norms and goals are in a position to shape the negotiation 
processes and outcomes. There is a peer review quality of the process: the validity of the arguments is constantly challenged, and only those ones that pass the normative test of the group are acknowledged (Lewis 2005). Arguments can be used in a strategic manner and, eventually, rhetorically entrap delegations (Thomas 2011).

Yet, arguments can also be used sincerely. In this latter case, EU foreign policy transcends intergovernmentalism in a more profound way. Part of the literature, building on constructivist insights, argues that EU foreign policy is collectively defined in Brussels (Juncos and Reynolds 2007). National officials are prepared to persuade and be persuaded, which helps to find a reasoned consensus in case of divergent views. Other practices are attached to this joint formulation of policies. When the national capital in on a different line, Brussels-based delegates often 'perform a second suasion or didactic function'. They convey to the capital the sense of collective European opinion and suggest 'ways in which national positions can be modified in order to achieve collective results' (Howorth 2012: 447). They act so as to convince their capital to change the original national position (Chelotti 2013).

The puzzle: rationalist outputs

To sum up: EU foreign policy is formulated, to a great extent, by (often Brussels-based) national bureaucrats; the process is characterised by a high number of cooperation-oriented practices, diffuse sentiments of loyalty to the group and possibly argumentative procedures. The system has indeed gone beyond intergovernmentalism. Yet, what are the outputs that a beyond-intergovernmental EU foreign policy produces? How significant are they? The literature on this issue is rather taciturn and/or inconclusive.

EU foreign policy is certainly a variegated field. A part from minor concerns that are dealt with directly by the EEAS, national diplomats face three types of issues (Chelotti 2016). First, on particularly sensitive/important topics (e.g., as the relationship between the CSDP and NATO or the member states' perspectives on the Eastern Partnership), representatives have very strict instructions or red-lines; the problem is either skipped or neutralised by using the agreed language (Bremberg 2016). Although it is difficult (if not arbitrary) to give percentages, this occurs roughly for the $10-20 \%$ of the issues under discussion. Second, a number of issues (oscillating between $20 \%$ and $40 \%$ ) are relatively uncontroversial and are rapidly settled by diplomats. Member states have here similar views, with delegations pushing for including a greater emphasis on human rights or on rule of law. The real 
negotiations occur in relation to the third type of issues. They might amount to around 50$60 \%$ of the cases and include topics such as the Arab spring, the crisis in Ukraine or funding certain initiatives. If we exclude the second type of issues, how substantial are the decisions reached by CFSP/CSDP officials?

A frequent advice of the literature on diplomacy or practices is to listen what practitioners have to say about their activities (e.g., Pouliot 2010; Sharp 2009). The research has asked CFSP/CSDP policymakers how they evaluate the outputs of their own negotiations. Arguably, the methodological centrepiece of a practice approach is ethnography and/or participant observation, as it might be difficult to unveil the taken-for-granted practices of diplomacy with more traditional methods of inquiry. This article relies on 138 questionnaires compiled by national delegates to CFSP/CSDP committees and 37 in-depth interviews. Although questionnaires and interviews force interviewees to rationalise the nature of their activities, the reason for this methodological choice is threefold. First, it is very difficult to have continual access to the CFSP/CSDP decision-making process. Negotiations are usually secretive and impenetrable. It does not come as surprise that Vincent Pouliot's book, International Security in Practice: The Politics of NATO-Russia Diplomacy, (only) uses interviews and secondary literature while not having the opportunity to partake in the deliberations he analyses (Hopf 2011).

Second, even if we had the possibility to attend, for an extended period, the meetings of one CFSP/CSDP settings (e.g., PSC), this would greatly limit the analysis, since it would exclude all the interactions that occur in the other sites of the CFSP/CSDP. Leaving aside the ministerial level, EU foreign/defence policy is formulated in a relatively conspicuous number of committees: the PSC, EUMC, CIVCOM and the around 30 working groups of the Foreign Affairs Council. The questionnaire was sent to all the national decision-makers ${ }^{2}$ that participated in all these venues in the spring of 2008. The response rate was around 36\% (138 replies). Interviewees were given two options: they could respond to either the postal or the on-line questionnaire. They overwhelmingly favoured (114 versus 24) the first, more traditional option. I received replies from all the (then 27) member states, although from two countries only one answer was obtained. ${ }^{3}$ No noticeable patterns in the (lack of) response were detected, although, on a whole, older member states replied slightly more frequently

\footnotetext{
2 With the partial exceptions of the Coreper ambassadors and their Antici collaborators. For more methodological information, cf. Chelotti 2016.

${ }^{3}$ Around 10 interviewees preferred not to reveal their nationality. The 37 in-depth interviews were conducted with officials of 17 different states.
} 
than 'new' members. Significantly, another product of my research on the formulation of EU foreign policy revealed that the sample of the respondents included both nationally-oriented and pro-European diplomats (Chelotti 2015). Third, the strategy of using questionnaires aimed to achieve another goal - going beyond small-case evidence and giving a more solid illustration of the entire CFSP/CSDP decision-making process. We run the risk of losing the bigger picture of the diplomatic interactions if we investigate the activities of a few diplomatic groups or we explore in-depth a few case studies (Saurugger 2013).

So, how do diplomats see the outputs that a beyond-intergovernmental EU foreign policy produces? The query was formulated in order to detect what the most likely output was, of a typical CFSP/CSDP negotiation in case of divergent views. Officials were thus asked to refer to a sort of average conflictual case which would most commonly represent the diplomatic mood of the CFSP/CSDP. When interrogated about the outputs of conflictual situations, officials indicate that the final result is very likely to reflect rationalist logics (Table 1). By rationalist outputs, it is meant products of foreign policy which are envisaged and embodied by a rationalist understanding of EU policy processes. In European and international politics, national representatives would (still) seek to advance the national interests, as they (still) think that their main job is to obtain gains for their countries. The European political system remains on a whole state-centric, and the outputs are generally determined by the nationallyoriented geopolitical and economic considerations that state representatives make when negotiating.

Table 1 reveals that, in most cases, a conflicting situation leads to a decision which is either close to the position of the most powerful states or to the lowest common denominator (LCD). The results are rather similar in the two cases: $78 \%$ of the interviewees affirm that either solution happens frequently ('very' and 'fairly' options). In both cases, only two people said that this never happens. The limited relevance of the decisions is also considered a more likely event than a deal that is closer to the preferences of the most powerful countries: $30.7 \%$, versus $16.9 \%$ respectively, sustain that a similar description of the output is very accurate. 'There is more than some truth to this' (e.g., LCD), because 'at the end of the day, this is what you get with consensus'. ${ }^{4}$ Consensus is often more an end than a means. For instance, Council conclusions usually have very few 'innovations' because they 'very

\footnotetext{
${ }^{4}$ Permrepr\#33, July 2014.
} 
carefully ... express, sentence by sentence, the possible common position that everybody can agree on' at any time. ${ }^{5}$

Table 1. Most likely outcome of a conflictual situation (\%)

Certainly, interviewees sustain that in several cases EU foreign policy is able to escape these two logics and forge a different, perhaps more consequential, foreign policy. For instance, if we analyse more in-depth the scores for the LCD, we can see that the EU, at times, manages to transcend watered-down agreements. A national representative described the CFSP decision-making process as somewhat 'more than the lowest common denominator, [with] a distillation of the European interest' ${ }^{6}$ After all, the most selected of the four options was the second ('fairly true'), and around $22 \%$ of diplomats chose the third or fourth entry (Table 1). Space for more substantial decisions does exist, even in cases of conflicts. These more substantial decisions can have very different nature. First, they can simply reflect the fact that EU foreign policy is dictated by the most powerful states (see the other question in Table 1). The weight of the bigger states is what is able to break the gridlocks and possibly lead to significant choices. Second, they can take the form of inclusive compromises, where delegates are willing to offer costly and sizeable concessions, for instance through issuelinkages and side-payments. The system here produces decisions that go indeed beyond the LCD, but it nonetheless remains within a rationalist logic. If states agree to renounce to some aspects of their original position, they do it after carefully evaluating the costs and benefits of reaching an agreement. Finally, in some cases far-reaching decisions reflect an argumentative consensus, which might even revolve around some 'extreme' (but convincing) positions held by certain member states. The policy outputs of the CFSP/CSDP are fully concurred by the national delegates and represent reasoned understandings of a foreign policy issue (Juncos and Reynolds 2007). Yet, these cases appear few. On a whole, it is fair to say that, when states have different interests, national loyalties and power relations tend to prevail.

\section{The resilience of consequentialist practices}

\footnotetext{
${ }^{5}$ Permrepr\#28, July 2014.

${ }^{6}$ Permrepr\#27, June 2014.
} 
Transgovernmental networks, social (and argumentative) practices, we-feelings seem to produce overall nationally-oriented outputs. How do we explain this puzzle? EU foreign policy is effectively transgovernmental, for the most part; more, it is disaggregated to such an extent that Brussels-based officials assume important decision-making responsibilities, also in single capacity. There is no denial either that many practices make EU foreign policy a social field characterised by, inter alia, an extensive sharing of information, self-restraint, cooperative solutions and common normative standards.

Yet, these existing cooperation-friendly practices need to be put in a larger picture. First, transgovernmentalism refers to the process of international interactions while it is agnostic on the nature of the interactions' outputs. In other words, lack of direct government control as denoted by transgovernmental networks does not necessarily lead to substantive policy outputs. Autonomy can be a precondition (or a facilitating condition) of substantive/consensual/deliberative outputs, but it is in no way the same thing. Second, the entire practical context of EU foreign policy needs to be considered. In a reasonable effort to show that EU foreign policy is more than, and has moved beyond, intergovernmentalism, the literature has largely bracketed or underplayed the strength of consequentialist practices. By consequentialist practices it is meant ways of doing things that incorporate self-interested and instrumental calculations (cf. March and Olsen 1998). In the context of EU diplomacy, diplomats (still) act by roughly evaluating the alternatives and anticipating the consequences of their actions in the pursuit of national orientations.

Social practices certainly soften the pursuit of national interests and contribute to reduce the divergences in member states' foreign policies. But they have been added to a frame whose practical substance remains for a considerable part linked to national inclinations. In this sense, I argue that EU foreign policy is socially constructed only to a limited extent. On a meta-theoretical level, international politics, diplomacy, EU foreign policy are socially constructed through practices all the time (Adler 2008; Wendt 1992). Yet, on an empirical level, the actual content of these practices is not 'social' in another, narrower, sense. Sociallyoriented practices have not become prominent in EU foreign policy, so that policies are now collectively defined/argued in an Europeanised way and that the pursuit of national concerns has been overcome. Consequentialist practices are instead frequently performed and occupy, in many ways, a predominant position. 
After all, even those who claim that EU foreign policy has gone beyond intergovernmentalism recognise from time to time that social practices do not denote the complete loyalty transfer to a quasi-federal foreign policy, or the disappearance of national red-lines (e.g., Bicchi 2011; Chelotti 2016; Howorth 2012). But if this is true, and if, for instance, national diplomats are said to redefine 'national interests within a new Europeanised context' (Tonra 2003: 740), the interconnection between the national and the European should be properly problematized, clarified and unravelled. How does this interconnectedness function? How significant is the impact of collaborative practices over the ultimate nature of EU foreign policy? What are the implications of (now) Europeanised national interests for CFSP/CSDP policy outputs?

Again, the point is not so much whether/to what extent national negotiators act through practices. Rather, the point is to recognise the content of these practices. Nationally-inspired ways of doing things (still) constitute good extent of the practical/normative 'fabric' of the CFSP/CSDP. Put in different terms, consequentialist practices are (still) the anchoring practices in CFSP/CSDP negotiations (Bicchi and Bremberg 2016), as they provide the space around which other practices develop. The rest of the section specifies two consequentialist practices, and then discusses why changing (consequentialist) practices is a difficult process.

\section{Promoting the national interest}

There is no shortage of definitions of practices. The conceptual debate around them has concerned also the epistemological and ontological commitments of a practice approach (Bicchi and Bremberg 2016). Practices are here understood in a broad sense, and, in line with Adler's and Pouliot's (2011: 4) definition, they are seen as 'socially meaningful patterns of action', which 'simultaneously embody, act out, and possibly reify background knowledge and discourse in and on the material world'. The analytical focus is on the regular performance of a set of conducts by a specific group of actors (in this case, diplomats). These conducts are produced, reproduced and sustained on a recurring (and often tacitly legitimated) basis and become a stable way to structure the interactions among diplomats.

The first consequentialist practice shared by Council diplomats is the promotion of the national interests/positions, which is (still) their predominant activity and concern. This can seem relatively uncontroversial. In diplomacy, national representatives are required to advance the national interest. They receive a salary from national budgets to strike the best 
deals for their own country. But if this is true, and the promotion of the national interest remains national officials’ primary conduct in the highly iterative Council meetings, then the discourse around a distinctive, post-sovereign diplomacy in the EU (e.g., Adler-Nissen 2014) needs to be reformulated. Diplomats in Brussels certainly develop friendly relations. They are also more prone to sustain the European cause vis-à-vis bureaucrats in the capital, while sometimes acting to convince them to change national positions. The people in the capital are distant, and cannot properly understand (as Brussels-based diplomats do) 'the rationale of other member states' position'. ${ }^{7}$ Yet, on a whole, despite the strong interconnectedness among member states over the decades, national representatives largely take the stance they think it is in the best interest of their country (Trondal 2006). In many ways, the promotion of the national interest (which includes respecting each other's' national interest) can be considered the anchoring practice par excellence, around which, and in relation to which, the other (social, non-social, argumentative) practices gravitate.

Around $80 \%$ of the respondents to the questionnaire affirm that in case of diverging interests, reaffirming and defending national preferences is 'very' or 'fairly' common (Table 2). In CSDP, 'national interests really drive the process'. National interests are often engrained in well-established national traditions. The positions around these questions hardly change: 'if something comes [up], you can predict what actually one or the other delegation will say', with good approximation.' 8 These interests often derive from the different geopolitical positions or the different trade relations of the various member states. The United Kingdom (UK) is, for example, 'very well aware of their trade interests' and are very capable to make connections between their foreign policy and their trade policy. Even 'if an issue might not seem very political to our eyes, they might have strong financial or trade interests that would dictate their policy in that matter'. ${ }^{9}$

Table 2. Conflicting positions: negotiation practice

Entrenched national positions emerge not only in cases of visible geopolitical, security or economic interests. They often surface in the implementation of CFSP/CSDP decisions. 'Once we come into technical questions, then the positions differ'. The reason is that when states have to actually commit financial or human resources the tensions increase and the

\footnotetext{
${ }^{7}$ Permrepr\#26, June 2014.

${ }^{8}$ Permrepr\#21, June 2013.

${ }^{9}$ Permrepr\#30, July 2014.
} 
political will becomes less intense. Once 'we reach the level of' putting into practice certain political choices (e.g., a civilian mission), 'that's where I would trace differences in positions'. 10

The overall result is that 'after you've done certain negotiations and you are able to identify certain country blocs you' will never able to overcome, 'you become a bit cynical'. ${ }^{11}$ It is 'frustrating when you know in advance that a solution is dead-born because member state $\mathrm{X}$ or Y will oppose it, by definition and against all rationales'. ${ }^{12}$ One diplomat, knowing that I was writing a book on the formulation of EU foreign policy, gave me a clear advice: the 'one mistake to avoid is 'not to downplay the resilience of national interests' in Council negotiations. $^{13}$

Other consequentialist (sub)-practices, which are directed to reassert the national position, are also present in CFSP/CSDP negotiations. Misrepresenting one's goals or reservation price is one of them. One common tactic in negotiations is to 'start off with a rather hard position, and ... move toward the middle' only at the later stages of the negotiations. ${ }^{14}$ Negotiators need to carefully shield the intensity of their preferences as well as their eventual knowledge of other parties' real preferences. The well-prepared delegations 'are not afraid to get and stay tough. [If] they are backed up to the maximum ... they will not budge until they have got exactly' what they want. ${ }^{15}$ And when you see this game unfolding 'in front of your eyes', ‘it’s quite funny': even if ‘you know already a member state’s red-lines ... nonetheless you have to stay, play your role game and show that you haven't given up on that easily. It's part of ... how things work'. ${ }^{16}$

The idea that promoting the national interest is the anchoring practice in CFSP/CSDP negotiations is briefly substantiated through a few examples. Fostering the national position permeates the performance of other (social and argumentative) practices. Or, in different terms, these other practices are able to scrape the anchoring practice only to some extent. Firstly, negotiators report that their culture of compromise is pervaded by their desire to pursue the national goals. It is very 'important that you are fully aware of what you are giving

\footnotetext{
${ }^{10}$ Permrepr\#22, June 2013.

${ }^{11}$ Permrepr\#34, July 2014.

12 Permrepr\#4, May 2008.

${ }^{13}$ Permrepr\#34, July 2014.

${ }^{14}$ Permrepr\#33, July 2014.

${ }^{15}$ Permrepr\#28, July 2014.

${ }^{16}$ Permrepr\#34, July 2014.
} 
up' and what you are obtaining, 'in terms of your national interest' ${ }^{17}$ 'Did I get enough for my country compared with what other states got? [If it is so] you will make a compromise'. ${ }^{18}$ Secondly, several interviewees have underlined the selective use of European solidarity: they have noticed (and deplored) that some delegates are very ready to evoke these notions and ask their partners for solidarity, but are not quite as willing to reciprocate it when requested (Chelotti 2016). Thirdly, argumentative practices can be infused with an uncompromising disposition. In the PSC the presentation of the position 'depends on what the others have ... said [before you]... The substance of your position remains the same, but you have to present it as part of the [argumentative] context' ${ }^{19}$ The underlining, tacit, disposition of the national representative seems to be that of furthering his/her state's national interests.

\section{Preponderant role of the most powerful states}

The second consequentialist practice here discussed is the predominance of the most powerful states. Formally, there is no institutional arrangement that secures them a preeminent role. All the states have the same rights (including the same opportunities to veto) and share the same channels to influence negotiations. Yet, if power can be tamed in wellfunctioning institutions, it would be misleading to claim that it is completely removed once institutions have been established. Institutionalists underestimate the role of power in shaping their development and workings (Menon 2011). In diplomatic studies, one recent plea is to more explicitly explore the power-diplomacy nexus, and bring the issues of power into the analysis of the processes, change and innovation of diplomatic modes (Melissen 2011; Pouliot 2008: 282).

In the European Council, the most important single factor in explaining the outcomes of its negotiations is state power (Tallberg 2008). Participants recognise that differences in state power matter significantly. A veto exercised by Germany does not carry the same weight as the veto of Cyprus. As Jonas Tallberg reports (2008: 689),

'Hubert Védrine, former French minister of foreign affairs, [claims]: "What grants influence in the European Council is first and foremost the actual power of the

\footnotetext{
${ }^{17}$ Permrepr\#34, July 2014.

${ }^{18}$ Permrepr\#28, July 2014.

${ }^{19}$ Permrepr\#14, June 2008.
} 
country. A Member State's actual power is decided by its economy, demography, geography, political system and diplomatic reach.” Yet also representatives of small states testify to the impact of structural power resources. As Jean-Claude Juncker, long-serving prime minister of Luxemburg, states: “Greater Member States have a greater say. We never admit it, of course, but one has to acknowledge that geography and demography are playing a role.”,

An interesting point raised by Tallberg's interviewees is that power is deployed indirectly, not just through a vaster array of resources, but also because of a greater tacit legitimacy of its claims to influence. Similar findings are reported by a recent study on the negotiations in the Council. Daniel Naurin (2015) argues that France, Germany and the UK (the 'Big 3') play a different game compared to the rest of the crowd. They need to receive some explicit compensation before agreeing on an eventual output. They can break the group's norms without losing credibility and a strong voice in the process.

In CFSP/CSDP negotiations, the most powerful states - and, more specifically, the 'Big 3',20 - have an equally prominent weight (or even more so). Interviewees admit that the process is different when these three 'do not want something ... Some don't like it, especially new or smaller member states. They say 'well if we don't want something then it will happen anyway and if they don't, it doesn't happen', ${ }^{21}$ Negotiators recognize that power politics matters; 'this is the way it is done. [Within] NATO, you will be criticized because' the big role is played by the US: 'You pay: you have what you want. I don't think it's a bad thing ... it's simply the reality'. For example, it is true that the French ask 'for a mission in Mali, Niger and Horn of Africa ... but once the mission is established they will provide $75 \%$ of the staff. There you are'. ${ }^{22}$ In general, the most powerful states cannot exercise their influence through 'diktats' or 'impositions' ('it cannot be a diktat by three member states'), but instead need to 'work within the system' and follow the system's rules. ${ }^{23}$

\section{Changing practices}

\footnotetext{
${ }^{20}$ In CSDP, even if Germany recently appears more willing to invest resources and political capital in defence, the two most important countries remain the UK and France.

${ }^{21}$ Permrepr\#33, July 2014.

22 Permrepr\#32, July 2014.

${ }^{23}$ Permrepr\#31, July 2014. On burden-sharing in crisis management operations, cf. Mérand and Rayroux 2016.
} 
In Council negotiations, recurrent and sustained patterns of action involve the legitimacy of pursuing national interests and the predominance of the most powerful states. The normative thick environment of Brussels-based institutions have certainly created a whole set of social practices and made the negotiation process a cooperative enterprise. The 'classical', interstate features of diplomatic negotiations, however, are still very much present and shape the political processes and outputs (Naurin 2015).

From a practice perspective, this might be hardly surprising. One of the key insights of the approach is that, although they do change, practices are resilient and repetitive. Practices have a habitual quality. Especially like, in this case, the focus of analysis is on well-entrenched practices, which refers to historically accumulated trajectories, changing practices is difficult. In arguing that habitus is dispositional, Vincent Pouliot (2008) identifies spaces for change and contingency in social action. He nonetheless reminds that this contingency can be (highly) limited: 'agents "improvise” within the bounds of historically constituted practical knowledge' (Pouliot 2008: 282). Ted Hopf is much more resolute in claiming that change is a rare phenomenon in international politics. He forcefully indicates that practices (or habits, as he mostly refers to) are structural obstacles to political change. The 'unexamined and predisposing structure of habits strongly anchors actors' perceptions, attitudes, and practices toward the status quo' (Hopf 2010: 545).

Change is difficult, practices are repetitive. If EU foreign policy has instead gone (well) beyond traditional and established ways of doing (inter-state) diplomacy, the mechanisms of such (a big) change should be clearly spelled out and demonstrated. It is here where the literature has generally failed. It has failed to convincingly show how nationally-oriented practices have been subsumed by social ones, or at least, how they have been substantively altered in their functioning and logic (Johnston 2001; Sarugger 2013).

The important question to be asked is therefore: how did change eventually happen? What are the sources of change? Merely revealing that social practices have been added to CFSP/CSDP negotiations, and that national officials comply with these procedural, substantive or argumentative standards, is not enough. Significantly, it does not mean that traditional, inter-state ways of solving conflicts have been overcome. The right balance between these different types of practices should be explicitly and thoroughly confronted, along with their eventual interaction. If pro-cooperation practices have only been an addition, and have only slightly modified the conduct of EU foreign policy, the entire quality of the claims changes. The latitude of the theoretical and empirical ambitions of a beyond- 
intergovernmental EU foreign policy would need to be scaled down. On a whole, the consequences of this move should be more lucidly drawn, including with regard to the alleged distinctive and novel nature of the EU as political actor.

Arguably, one of the possible sources of change frequently mentioned in the literature is socialization - which can include different micro-processes, such as persuasion and social influence (Johnston 2001). The work on this subject, however, still has a lot to demonstrate. The literature on socialization in Europe has convincingly shown that a European identity is, at best, only ancillary and secondary to national affiliations. Especially in the Council, national officials mainly see themselves as representatives of their government. It is simply too early to talk of an independent, robust, superordinate, and strong European social/collective identity', whereas what we see is that national-level logics often dominate European socialization (Zürn and Checkel 2005: 1067). At stake there is also the behavioural dimension of socialization - that is, whether, to what extent and how diplomats' new orientations result in shifts in state policies. Socialization research should show not only that these phenomena have some sort of conceptual legitimacy, but it should define how much socialization matters, in what aspects and with what consequences. The ultimate test might be to prove that the legitimacy of the socialising institution (i.e., CFSP/CSDP committees) is so strong that national delegates 'are unwilling to undermine [the socialising institution] even on issues where they have strong and divergent state preferences' (Johnston 2005: 1019). Again, the transformative character of socialization processes in EU foreign policy must be carefully demonstrated, not (usually tacitly) assumed.

\section{Diplomats, practices and the micro level}

The previous sections have introduced and discussed a number of practices, within a certain narrative of CFSP/CSDP negotiations: practices are resilient, and consequentialist ways of solving conflicts still provide the anchoring structure of the diplomatic space. Here, the analysis zooms more closely into the sites where Europe is done and practices are reproduced. The aim is to uncover a bit more the understandings that occur at the micro-level around the performance of these practices. If the previous sections have argued that EU foreign policy takes place within nationally-orientated foreign policies, one of the main insights of this section is to acknowledge that within the boundaries of these well-established 
national positions, space for agency nonetheless exists. Certain practices can be performed in a number of different ways, which are all reasonably acceptable and accepted by the national governments. A lot of different factors - including characteristics of individual diplomats then intervene to determine which of the various ways are actually pursued in EU negotiations.

This section elaborates on the meanings that diplomats attach to the context surrounding five negotiating activities/items: a) veto; b) lowest common denominator; c) powerful states; d) positions’ change; e) autonomy.

Veto. Veto is almost immediately associated to red-lines. Red-lines usually revolve around well-known points: 'of course there are a couple of issues in our foreign policy ... where we do stick to our position no matter what'. ${ }^{24}$ Most of the time, red-lines come from the capital which then decide to maintain the point even after negotiations have started. However, it might happen that the initiative comes from the diplomat himself/herself, who identifies 'an issue where you see a red-line approach' and then reports back to the capital. ${ }^{25}$ It is in these cases that the involvement of the capital in the decision-making process is at its strongest. In order to exercise veto, the diplomat needs to have the backing of the national administration. 'You can only stick to your position' if you 'can have the coverage of your minister and perhaps even your Prime Minister'. If 'all of a sudden your minister says “Oh but let it go”, you would entire lose your credibility'. ${ }^{26}$ A red-line does not have necessarily to turn into a veto. Another possibility is that the group works together with the recalcitrant delegation to come up with a document which incorporates the provisions of the red-line.

Lowest common denominator. Diplomats seem to immediately grasp the circumstances around an output based on the LCD. They relate it to the necessity of having consensus and the unanimity rule. On a whole, they tend to agree that these features 'smooth out the most exciting ideas'. ${ }^{27}$ But officials appear uncomfortable with the sheer admission of producing LCD outputs. They are very quick to claim that LCD has a 'pessimistic' connotation and 'most of the times I would be on the positive side, ${ }^{28}$ : 'I think it is a bit more than the sum of

\footnotetext{
${ }^{24}$ Permrepr\#33, July 2014.

${ }^{25}$ Permrepr\#31, July 2014.

${ }^{26}$ Permrepr\#33, July 2014.

${ }^{27}$ Permrepr\#35, July 2014.

${ }^{28}$ Permrepr\#30, July 2014.
} 
its parts ... more than pure mathematics', as 'there is a sense of wanting to be together, have solidarity and defend our principles and values'. ${ }^{29}$ National delegates also provide examples of rather innovative solutions, which 'you would not have expected' from the range of state interests (e.g., Middle East peace process, engaging in Libya, EUCAP NESTOR). ${ }^{30}$ They do not necessarily work out, but 'to call it the lowest common denominator gives it negative connotations and I don't think it’s justified' ${ }^{31}$

A very important point to consider is that 'there are no 28 independent foreign policies, never [have] been, never will be'. There is 'one third for [a certain proposition], one third against [and] one third: I don't know'. The LCD is therefore the 'lowest common denominator of those thirds', i.e., 'between the first two thirds'. ${ }^{32}$

Powerful states. Power, diplomacy and practices are all strictly related. Participating in a practice involves the exercise of power, which has both material and symbolic elements (Pouliot 2008). Diplomats recognise in many ways that the Big 3 have a special influence in EU foreign policy. But they have a more multidimensional understanding of power. First, there is also a 'second circle of insiders', which includes Italy, Spain ('the Quint') and Poland ('the Big 6'), which forms 'the core of EU foreign policy'33 Second, power is also functionally differentiated, and depends on the policy issue or region. For instance, Portugal is one of the key countries in discussions over certain parts of Africa and Latin America, Belgium is most active in the case of Congo and Malta in the case of Libya. ${ }^{34}$ In this vein, powerful states are those states that are particularly active on a specific issue. ${ }^{35}$ Along similar lines, a third dimension of power refers to the actual interest that a country has in one topic interest which is operationalised in terms of the ability to obtain and share precious information or the capabilities a state is willing to put on the table. ${ }^{36}$ Finally, power has also a social perspective. In order to acquire a powerful position in the diplomatic game, negotiators develop certain social skills and ties in line with the requirements of their field (Kuus 2015). Power has thus also an individual quality, and the individual characteristics (experience,

\footnotetext{
${ }^{29}$ Permrepr\#24, June 2013; Permrepr\#23, June 2013.

${ }^{30}$ Permrepr\#30, July 2014.

${ }^{31}$ Permrepr\#35, July 2014.

32 Permrepr\#29, July 2014.

${ }^{33}$ Permrepr\#28, July 2014. Also: Permrepr\#27, June 2014; Permrepr\#31, July 2014

${ }^{34}$ Permrepr\#24, June 2013; Permrepr\#28, July 2014

35 Permrepr\#27, June 2014; Permrepr\#28, July 2014

${ }^{36}$ Permrepr\#3, May 2008; Permrepr\#5, May 2008; Permrepr\#23, June 2013.
} 
prestige, education, etc.) of the diplomat can have an impact on the processes and outcomes of negotiations (Tallberg 2008).

Change in positions. If diplomats' responses indicate a rather clear awareness of the meanings around vetoes, LCD and power, they struggle in making sense of policy changes. There is no doubt that positions change repeatedly (Chelotti 2013). Yet, when questioned why or in what ways this occurs, the request did not seem to carry any real meaning to them. The underlying mechanisms of policy shifts seem commonsensical to them. 'Change occurs because you make deals ... When you have flexible positions, you can reach a compromise'. ${ }^{37}$ The same notion of change is questioned:

'I would not use the word 'change'. The positions are moderated ... During the negotiations, some countries or some questions might become more moderate, and other countries might become more agitated and active ... I observe that those who are directly involved must get something from these negotiations. ... [So], positions don't really change, what changes is the perception of where the agreement lies'. ${ }^{38}$

There is an agential element in performing these practices. Moving, moderating or changing the national position depends on the flexibility of the instructions but also on 'the imaginational invention of the negotiators'. ${ }^{39}$ Brussels-based negotiators are very active in identifying and striking deals and have (independent) room for making compromises. They report back to the capital in a second moment, trying to 'convince [them] that we won, maybe not $100 \%$ but we are still the winner'. 'You can sell it [to the capital] because they don't have this [and] you have this and this and this'. ${ }^{40}$ The individual features (experience, personality, etc.) of the various diplomats here can play a role in the policy making. At the micro level, practices can be performed in different ways by national officials, who can reach (slightly) different points of equilibrium.

Autonomy. Diplomats frequently report that they work under instructions, but at the same time they feel sufficiently autonomous in their negotiating activities. 'You're not just here as

\footnotetext{
${ }^{37}$ Permrepr\#23, June 2013.

${ }^{38}$ Permrepr\#22, June 2013.

${ }^{39}$ Permrepr\#26, June 2014.

${ }^{40}$ Permrepr\#32, July 2014.
} 
a post-box: you have brains, so you [better] need to use them'. ${ }^{41}$ What is the meaning they attach to autonomy? First, autonomy is associated to the input they have in negotiating their own instructions with the capital (Chelotti 2013, 2016). Negotiating with the capital takes $60 / 65 \%$ of their time, because the ministry often comes from a position which is out of tune with the Brussels-based debates. ${ }^{42}$ There is plenty of evidence that the capital 'listens to us [e.g., Brussels-based diplomats], meaning that we can have an impact on [national] positions'. 43

Second, as instructions are not prepared for every topic on the agenda, the state negotiating behaviour when this happens is de facto decided by the national delegate. S/he might decide to stay silent or s/he might 'personally like to take part in the debates'. ${ }^{44}$ Third, autonomy refers to the leeway diplomats enjoy during the decision-making process 'on how to negotiate and how far to push, what issues to give up ${ }^{45}$. Instructions often suggest the state objectives, while the means to achieve them is largely left in the hand of Brussels-based officials. Fourth, autonomy ultimately means that 'you know the general lines from the capital and then you adapt it' to the circumstances', that 'you know your basic positions and their particular points where you have specific instructions but otherwise you do have certain leeway' ${ }^{46}$ This is a mix of partial agency in performing practices and the persistence (and anchoring) of the overarching national disposition. Diplomats make sense of their leeway by keeping the national context as the central point of reference. They know that they are ultimately accountable to their ministry (and some of them, also to their Parliaments). ${ }^{47}$

\section{Conclusion}

Despite the potentially transformative quality of the EU policy process, this article has argued that the social construction of EU foreign policy is (still) partial. If diplomats act though practices all the time, the empirical content of these practices in EU foreign policy is more

\footnotetext{
${ }^{41}$ Permrepr\#37, July 2014.

${ }^{42}$ Permrepr\#33, July 2014.

${ }^{43}$ Permrepr\#25, June 2014.

${ }^{44}$ Permrepr\#22, June 2013.

45 Permrepr\#31, July 2014.

${ }^{46}$ Permrepr\#34, July 2014.

${ }^{47}$ Permrepr\#7, May 2008.
} 
geared toward national logics and less collectively orientated than what some constructivists would expect.

The policy making is decentralised and mostly transgovernmental. Brussels-based officials are not closely guided in all their negotiating activities by the capital/executive, but they enjoy significant autonomy in performing their duties. Space for (individual) agency also exists. Yet, this autonomy does not necessarily lead to a collective legitimization of policies. Autonomy and an overall national understanding of the decision-making process (can and do) coexist. A systematic empirical investigation of CFSP/CSDP outputs (Bicchi 2011: 1128; Sjursen 2011: 1086), based on 138 questionnaires and 37 interviews, has revealed that conflicting states interests very frequently lead to decisions which resemble LCD logics and/or the positions of the most powerful states. Consequentialist practices are still largely present in EU foreign policy and often dominate over more social ones. Crucially, this does not apply only to the $10-20 \%$ of cases where red-lines apply, but national thinking is very much present in cases of divergent positions. Social and argumentative practices are common features of EU foreign policy, but they seem to intervene to soften, and not subordinate, nationally-oriented dynamics. The literature has often failed to comprehensively address the interaction between social and consequentialist practices, and has often taken too much for granted that autonomy would be predominantly characterised by social relations (Johnston 2005; Zürn and Checkel 2005). (Consequentialist) practices are resilient and difficult to change. The sources and mechanisms of change (and eventual subordination/obsolescence of intergovernmental practices) would need to be more convincingly investigated, tested and (eventually) proved. Put in different terms, if the decision-making process of EU foreign policy has certainly gone beyond intergovernmentalism, a focus on the outputs seems to indicate that it is has not (yet?) grown very far away, and it might be still nearby.

\section{Bibliography}

Adler, E., and Vincent Pouliot (2011). International practices. International Theory, 3 (1), 136. 
Adler-Nissen, R., 2014. Opting Out of the European Union: Diplomacy, Sovereignty and European Integration. Cambridge: Cambridge University Press.

Bicchi, F., 2011. The EU as a community of practice: foreign policy communications in the COREU network. Journal of European Public Policy, 18 (8), 1115-1132.

Bicchi, F., and Bremberg, N., 2016. European diplomatic practices: contemporary challenges and innovative approaches. European Security, 25 (4), xx-xx.

Bremberg, N., 2016. Making Sense of the EU's Response to the Arab Uprisings: Foreign Policy Practice at Times of Crisis. European Security, 25 (4), xx-Xx.

Chelotti, N., 2013. Analysing the Links between National Capitals and Brussels in EU Foreign Policy. West European Politics, 36 (5), 1052-1072.

Chelotti, N., 2015. A Diplomatic Republic of Europe? Explaining Role Conceptions in EU foreign policy. Cooperation and Conflict, 50 (2), 190-210.

Chelotti, N., 2016. The Formulation of EU Foreign Policy. Socialisation, Negotiations and Disaggregation of the state. London: Routledge.

Cross, M. Davis, 2011. Security Integration in Europe: How Knowledge-based Networks are Transforming the European Union. Ann Arbor: University of Michigan Press.

European Council of Foreign Relations, 2015. European Scoreboard, http://www.ecfr.eu/scorecard/2015

Hopf, T., 2010. The logic of habit in International Relations. European Journal of International Relations, 16 (4), 539-561. 
Hopf, T., 2011. Review of Vincent Pouliot 'International Security in Practice: The Politics of NATO-Russia Diplomacy’. Perspectives on Politics, 9 (3), 772-773.

Howorth, J., 2012. Decision-making in security and defense policy: Towards supranational inter-governmentalism? Cooperation and Conflict, 47 (4), 433-453.

Johnston, A.I., 2001. Treating International Institutions as Social Environments. International Studies Quarterly, 45 (4), 487-515.

Johnston, A.I., 2005. Conclusions and Extensions: Toward Mid-Range Theorizing and Beyond Europe. International Organization, 59 (4), 1013-1044.

Juncos, A., and Reynolds, C., 2007. The Political and Security Committee: Governing in the Shadow. European Foreign Affairs Review, 12 (2), 127-147.

Keohane, R., and Nye, J., 1974. Transgovernmental Relations and International Organizations. World Politics 27 (1), 39-62.

Kuus, M. 2015. Symbolic power in diplomatic practice: Matters of style in Brussels. Cooperation and Conflict, 50 (3), 368-384.

Lewis, J., 2005. The Janus Face of Brussels: Socialization and Everyday Decision Making in the European Union. International Organization, 59 (4), 937-971.

March, J.G., and Olsen J.P., 1998. The institutional dynamics of international political orders. International Organization, 52 (4): 943-69.

Melissen, J., 2011. Diplomatic Studies in the Right Season. International Studies Review, 13 (4), 723-725. 
Mérand, F., and Rayroux, A., 2016. The practice of burden sharing in European crisis management operations. European Security, 25 (4), xx-xx.

Mérand, F., Hofmann, S., and Irondelle, B., 2010. Transgovernmental Networks in European Security and Defense Policy. European Integration online Papers, 14 (1), http://eiop.or.at/eiop/pdf/2010-005.pdf.

Naurin, D., 2015. Generosity in intergovernmental negotiations: The impact of state power, pooling and socialisation in the Council of the European Union. European Journal of Political Research, doi:10.1111/1475-6765.12104.

Pouliot, V., 2008. The logic of practicality: A theory of practice of security communities. International Organization, 62 (2), 257-288.

Pouliot, V., 2010. International Security in Practice: The Politics of NATO-Russia Diplomacy. Cambridge: Cambridge University Press.

Saurugger, S., 2013. Constructivism and Public Policy Approaches in the EU. From Ideas to Power Games. Journal of European Public Policy, 20 (6), 888-906.

Sharp, P., 2009. Diplomatic Theory of International Relations. Cambridge: Cambridge University Press.

Sjursen, H., 2011. Not so intergovernmental after all? On democracy and integration in European Foreign and Security Policy. Journal of European Public Policy, 18 (8), 10781095.

Slaughter, A-M., 2004. A New World Order. Princeton: Princeton University Press.

Smith, M.E., 2003. Europe's Foreign and Security Policy: The Institutionalization of Cooperation. Cambridge: Cambridge University Press. 
Tallberg, J., 2008. Bargaining Power in the European Council. Journal of Common Market Studies, 46 (3), 685-708.

Thomas, D.C., ed., 2011. Making EU foreign policy: national preferences, European norms and common policies. Basingstoke: Palgrave Macmillan.

Tonra, B., 2001. The Europeanisation of National Foreign Policy: Dutch, Danish and Irish Foreign Policy in the European Union. Aldershot: Ashgate.

Tonra, B., 2003. Constructing the Common Foreign and Security Policy: The Utility of a Cognitive Approach. Journal of Common Market Studies, 41 (4), 731-756.

Trondal, J., 2006. EU committee governance and the multilevel community administration. In: C.H. Hofmann and A.H. Turk, eds., EU Administrative Governance. Cheltenham: Edward Elgar, 391-416.

Wendt, A., 1992. Anarchy is what States Make of it: The Social Construction of Power Politics. International Organization, 46 (2), 391-425.

Zürn, M., and Checkel, J., 2005. Getting Socialized to Build Bridges: Constructivism and Rationalism, Europe and the Nation-State. International Organization, 59 (4), 1045-1079. 
Table 1. Most likely outcome of a conflictual situation (\%)

\begin{tabular}{|l|c|c|}
\hline & Most powerful states & Lowest common denominator \\
\hline 1. Very true & 16.9 & 30.7 \\
\hline 2. Fairly true & 61.0 & 47.4 \\
\hline 3. Little true & 20.6 & 20.4 \\
\hline 4. It never happens & 1.5 & 1.5 \\
\hline Total & 100 & 100 \\
\hline
\end{tabular}

Table 2. Conflicting positions: negotiation practice

\begin{tabular}{|c|c|}
\hline & Reaffirming the national position \\
\hline Very often & 21.9 \\
\hline Fairly often & 58.4 \\
\hline Sometimes & 16.8 \\
\hline (Almost) never & 2.9 \\
\hline Total & 100 \\
\hline
\end{tabular}

